(Jpn. J. Hosp. Pharm.

資 23 (5) $437-444(1997)$

\title{
アルファカルシドール製剤成分含量に及ぼす保存環境の影響
}

\author{
中村裕義*, 木村真春, 山形畺一, 中村 均, 大森 栄, 北田光一 \\ 千葉大学医学部附属病院薬郕部门
}

\section{Effect of Preservative Environment on Alfacalcidol Content in Preparations}

\author{
HIROYOSHI NAKAMURA*, MAHARU KIMURA, SHIN-ICHI YAMAGATA, \\ HITOSHI NAKAMURA, SHIGERU OHMORI and MITSUKAZU KITADA \\ Department of Pharmacy, Chiba University Hospital $\dagger$
}

\author{
$\left(\begin{array}{l}\text { Received November 19, } 1996 \\ \text { Accepted April 30, 1997 }\end{array}\right)$
}

In the present study, we examined the effects of light, temperature and humidity on the residual rate of alfacalcidol in four commercially available preparations of alfacalcidol (Alfarol ${ }^{\circledR}$ capsules, Alfarol ${ }^{\circledR}$ powder, Warkmin ${ }^{\circledR}$ capsules and Onealfa ${ }^{\circledR}$ tablets). The tests were performed for up to 10 weeks with PTP seals, or without PTP seals. The changes in residual rate of alfacalcidol in Alfarol ${ }^{\circledR}$ powder packaged with cellophane-laminate paper, and Onealfa ${ }^{\circledR}$ tablets packaged with cellophane-laminate paper after crushing were also examined.

The residual rate of alfacalcidol decreased in Alfarol ${ }^{\circledR}$ capsules packaged with PTP seals under fluorescent lighting (1000 lux) and in Alfarol $^{\circledR}$ powder without an aluminum seal under all conditions. There were no changes in the contents of alfacalcidol in Alfarol ${ }^{\circledR}$ capsules with PTP seals and Alfarol ${ }^{\circledR}$ powder packaged by aluminum seal. A slight decrease in the residual rate of alfacalcidol in Warkmin ${ }^{\circledR}$ capsules was found under fluorescent lighting. The residual rate of alfacalcidol decreased in Onealfa ${ }^{\circledR}$ tablets under high temperature and/or high humidity. Alfarol ${ }^{\circledR}$ powder packaged with cellophane-laminate paper and Onealfa ${ }^{\circledR}$ tablets packaged with cellophane -laminete paper after crushing were found to be unstable, indicating that long-term storage should be avoided when these formulations are prepared.

Key words — alfacalcidol, stability, residual rate, high-performance liquid chromatography

\section{緒言}

アルファカルシドール製片は, 副甲状腺機能低 下症, 骨軟化症等の治療において広く有用性が認 められており ${ }^{1,2)}$, 軟カプセル剤, 錠剤, 散凨, 液剤等の凰形が複数のメーカーより発売されてい

$\dagger$ 千葉県千葉市中央区亥莮1-8-1;1-8-1，Inohana, Chuo-ku, Chiba, 260 Japan
る.アルファカルシドール製骫成分含量に及ぼす 保存環境の影響に関しては，インタビューフォー ムの“製剤に関する項目”に記載がなされている. しかしながら，その試験は最終包装で行われてい たり，PTP シートから取り出した状態での試験が なされていなかったりと, 実際に患者の手に渡っ た後の安定性がどの程度であるか, また, 交付の 際に患者に対してどのような保存上の注意を提供 
すべきかを知るためには不十分な条件設定である と言わざるを得ない.

また，実際に錠剤を粉砕して調剤したり，散剤 を分包して調片して患者に交付するケースもある ことから調剤後の成分含量の低下が問題となる可 能性も考えられる。しかし，これまでにアルファ カルシドール液剤の調剤後の光安定性に関する報 告3)がなされている以外，アルファカルシドール 製剤の調剤後の安定性に関する報告は見られな い.

そこで今回著者らは，軟カプセル剤であるアル ファロールカプセル, ワークミンカプセルとアル ファロール散，ワンアルファ錠の 4 製剤のアル ファカルシドール含量を HPLC 法により定量 し, 光, 温度, 湿度 $(\mathrm{RH})$ 等の保存条件の違い, 剤形の違いによる残存率の変化について検討を行 った.また,アルファロール散をセロハンラミネー トの分包紙で分包後の残存率の変化, ワンアル ファ錠粉砕後の残存率の変化についても合わせて 報告する。

\section{方法}

\section{1. 試験方法}

試験に用いた製剤は，アルファロールカプセル $0.5 \mu \mathrm{g}$ （中外製薬，Lot G5F 02），アルファロー ル散 $1 \mu \mathrm{g}$ (中外製薬, Lot G4G 01)，ワークミン カプセル $0.5 \mu \mathrm{g}$ (グレラン製薬, Lot 063)，ワン アルファ錠 $0.5 \mu \mathrm{g}$ （帝人, Lot 5360 ) の 4 種類で ある。

アルファロールカプセル， ワークミンカプセル は PTP包装の状態（シール）と PTP包装から取 り出した裸の状態（バラ）で試験を行った。ワン アルファ錠はカプセル剤と同様，シールの状態と バラの状態，さらに錠剤を乳鉢で粉砕して 1 包 0.3 中に 2 錠分を含有するように乳糖を加え賦形 し，セロハンラミネートの分包紙で分包したもの （分包）で試験を行った。アルファロール散は， アルミパック包装の状態（シール），シールを開 けて厚さ $5 \mathrm{~mm}$ でシャーレに撒いたもの（バ
ラ），七ロハンラミネートの分包紙で 1 包 $1 \mathrm{~g}$ と なるように分包したもの（分包）で試験を行っ た。

試験条件は，光による影響をみる条件として， 照度 1000 ルクスの蛍光灯下 $\left(25^{\circ} \mathrm{C} / \mathrm{RH} 50 \%\right)$ ，温 度・湿度による影響をみる条件として， $25^{\circ} \mathrm{C} / \mathrm{RH}$ $50 \%, 25^{\circ} \mathrm{C} / \mathrm{RH} 75 \%, 40^{\circ} \mathrm{C} / \mathrm{RH} 50 \%, 40^{\circ} \mathrm{C} / \mathrm{RH}$ $75 \%$ の合計 5 条件で試験を行った。ただしワンア ルファ錠の分包とアルファロール散の分包につい ては $25^{\circ} \mathrm{C} の 3$ 条件で試験を行った。なお，温度， 湿度の調整は恒温恒湿器（タバイエスペック社 製，LH-112T)を用いて行った。

アルファカルシドールの含量測定は, 開始 時, $2,4,6,10$ 週後の計 5 ポイントで行った.

\section{2. 定量方法}

各製剤中のアルファカルシドール含量の定量は HPLC 法にて行った。アルファカルシドール測定 の HPLC 条件を Table 1 に示した。なお検量線 は，1回にHPLCに注入するアルファカルシ ドールが約25～50ng であることから，5～100ng の間の 6 点から作成した.アルファロールカプセ ル, アルファロール散, ワンアルファ錠の HPLC 条件打よびワータミンカプセルの HPLC 条件に おける検量線はともに良好な直線性が得られ，相 関係数はそれぞれ $\mathrm{r}=0.9998$ おび1.0000であっ た。また，繰り返し10回による変動係数はそれぞ れ1.1\%および0.6\%であった。

各製剤の測定に際しての前処理方法を以下に記 す.

1) アルファロールカプセル

本品 5 個の重量を精密に量り，カプセルを切り 開いて内容物を取り出した。カプセルをへキサン でよく洗い, 乾燥後カプセルの重量を精密に量 り，カプセル重量を差し引いた值を内容物の重量 とした。内容物をよく混ぜ，その約 $0.12 \mathrm{~g}$ を精密 に量りへキサン $1 \mathrm{ml}$ を加えて溶解した。この液 を固相抽出用力ラム $(6 \mathrm{cc} / 1 \mathrm{~g} \mathrm{Si})$ に吸着させ た後，ヘキサン $8 \mathrm{ml}$ 及びへキサン・エタノール 混液 $8 \mathrm{ml}(97: 3)$ で洗浄した。次にエタノール 4 
Table 1. H P L C条件

\begin{tabular}{|c|c|c|}
\hline & 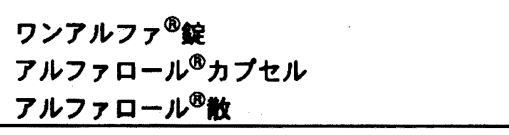 & ワークミンカカプセル \\
\hline ポンブ & $L-6000$ (日立) & 655 A-11 (日立) \\
\hline 買出唖 & L-4 200 (日立) & $638-41 \quad$ （日立） \\
\hline 波 長 & $265 \mathrm{~nm}$ & $265 \mathrm{~nm}$ \\
\hline カラム & Inertsil ODS - III $(4.6 \mathrm{~mm} \times 150 \mathrm{~mm})$ & Lichrosorubu Si60 $(4 \mathrm{~mm} \times 250 \mathrm{~mm})$ \\
\hline カラム温度 & $25^{\circ} \mathrm{C}$ & $25^{\circ} \mathrm{C}$ \\
\hline 移㔚相 & $\begin{array}{l}\text { アセトニトリル・水・䣫酸 } \\
(870: 130: 1)\end{array}$ & $\begin{array}{l}\text { ジクロロメタン・THF・Xタノール・水 } \\
(760: 28: 12: 2)\end{array}$ \\
\hline 流 速 & 1. $3 \mathrm{ml} / \mathrm{min}$ & $0.7 \mathrm{ml} / \mathrm{min}$ \\
\hline １５泬液 & 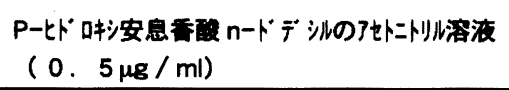 & $\begin{array}{l}\text { レソルシンの移娌相浴液 } \\
(2 \mu \mathrm{g} / \mathrm{ml})\end{array}$ \\
\hline
\end{tabular}

$\mathrm{ml}$ で溶出した後, 溶媒を留去し, 残留物に内部 標準物質（IS）溶液 $1 \mathrm{ml}$ を正確に加えて溶解し たものを試料溶液とした。試料溶液 $50 \mu \mathrm{l}$ を HPLC 分析に使用した.

2) アルファロール散

本品の約 $1 \mathrm{~g}$ を精密に量り, ジクロルメタン 4 $\mathrm{ml}$ を正確に加えて約20秒間激しく振り混ぜた 後, HPLC 用前処理フィルター $(\phi 0.22 \mu \mathrm{m})$ で ろ過した。弓液 $2 \mathrm{ml}$ を正確に量り，溶媒を留去 した後, 残留物に IS 溶液 $1 \mathrm{ml}$ を正確に加えて溶 解したものを試料溶液とした。試料溶液 $50 \mu \mathrm{l}$ を HPLC 分析に使用した.

3) ワークミンカプセル

本品 5 個の重量を精密に量った後, カプセルを 切り開いて内容物を取り出した。カプセルをへキ サンで洗浄, 乾燥後カプセルの重量を精密に量 り, カプセル重量を差し引いた值を内容物の重量 とした.内容物をよく混ぜ，その約 $0.1 \mathrm{~g}$ を精密 に量り, IS 溶液 $1 \mathrm{ml}$ を正確に加えて溶解したも のを試料溶液とした。試料溶液 $50 \mu \mathrm{l}$ を HPLC 分 析に使用した。

4) ワンアルファ錠

シールおよびバラについては錠荗 5 個の重量を 精密に量り, 乳鉢でよくすりつぶし, その約 0.17 $\mathrm{g}$ を秤取した．分包した試料については約 $0.3 \mathrm{~g}$ を 精密に量り，以下アルファロール散と同様の方法 により行った。

\section{3. 残存率算出法}

各測定ポイントにおける残存率は, 試験開始時 における各製剤中のアルファカルシドール含量を 100\%として算出した.

\section{結果}

$25^{\circ} \mathrm{C} / \mathrm{RH} 50 \%$ 条件下における 4 種のアルファ カルシドール製浏の残存率の変化を Fig. 1 に示 す．測定は各ポイントで 3 回行い，その平均值を 示した.なお， 3 回測定データの変動係数はすべ て $5 \%$ 以下であり.グラフに誤差線の表示はしな かった。シールの状態においては，いずれの製浏 も残存率に10週後まで変化は認められなかった. バラの状態では，アルファロール散の残存率は 2 週後で約 $5 \%$ と著しく低下した。一方，アルファ ロール散以外の製剤では，10週までの残存率低下 は認められなかった。

$25^{\circ} \mathrm{C} / \mathrm{RH} 75 \%$ の条件下における残存率の変化を Fig. 2 に示す. シールの状態では $25^{\circ} \mathrm{C} / \mathrm{RH} 50 \% の$ 条件下の時と同様，いずれの製剤も10週までの残 存率低下は認められなかった。バラの状態におい 


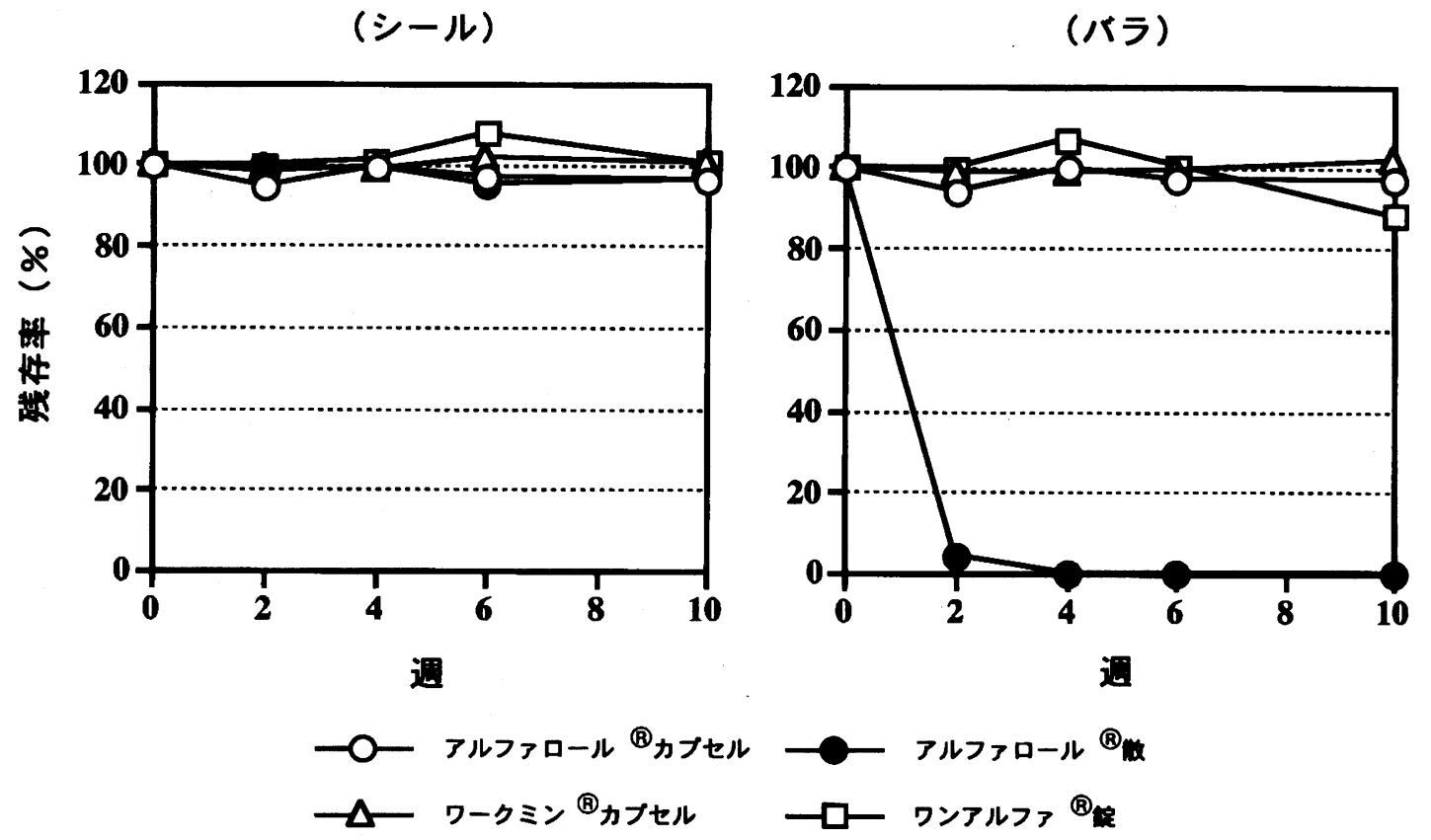

Fig. 1. $25^{\circ} \mathrm{C}, \mathrm{RH} 50 \%$ （遮光）の条件下における

各種製剤のアルファカルシドール残存率の変化
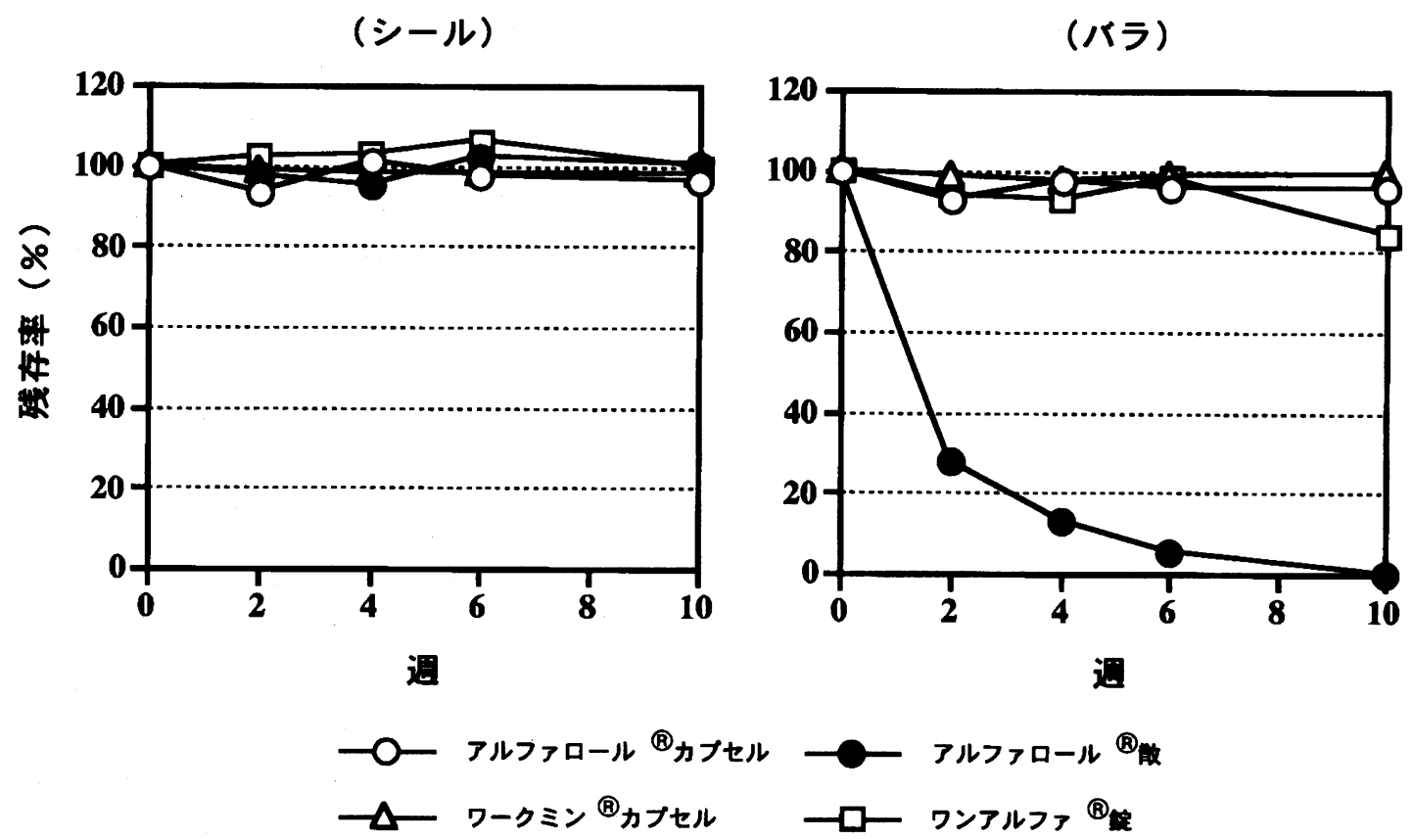

Fig. 2. $25^{\circ} \mathrm{C}, \mathrm{RH} 75 \%$ (遮光) の条件下における 各種製剤のアルファカルシドール残存率の変化 
(シール)

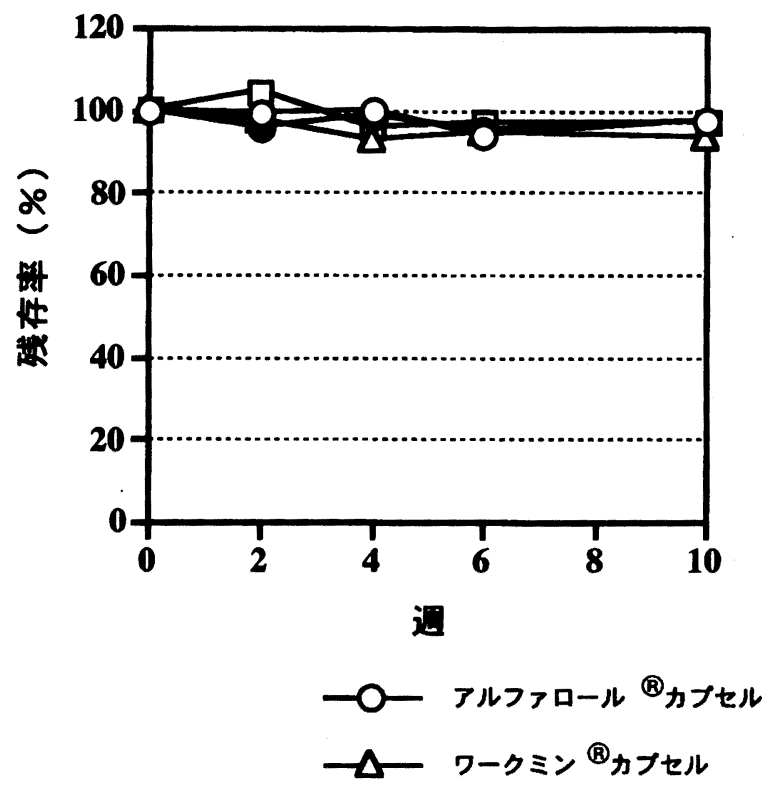

(パラ)

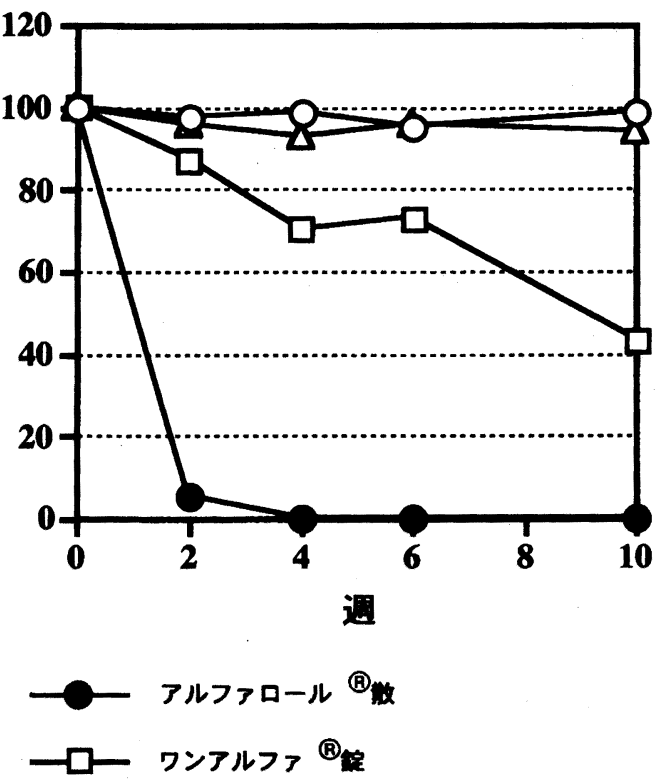

Fig. 3. $40^{\circ} \mathrm{C}, \mathrm{RH} 50 \%$ (遮光) の条件下における

各種アルファカルシドール製剤の残存率の変化

ては，アルファロール散の著しい残存率低下が認 められたが, $25^{\circ} \mathrm{C} / \mathrm{RH} 50 \%$ の条件の時と比べると 残存率低下は若干緩やかであった。 ワンアルファ 錠は10週後で残存率が約 $85 \%$ と若干の低下が認め られた。また，軟カプセル 2 剤はいずれも残存率 低下は認められなかったが, RH75\%の条件下で はシールの状態においてもカプセル皮浏の軟化が 認められ, PTP シールからの取り出しが困難とな った.

$40^{\circ} \mathrm{C} / \mathrm{RH} 50 \%$ の条件下における残存率の変化を Fig. 3 に示す. $25^{\circ} \mathrm{C}$ 条件の時と同様, シールの 状態ではいずれの製片も10週までの残存率低下は 認められず，バラの状態ではアルファロール散の 著しい残存率低下が認められた。 また，バラの条 件下でワンアルファ錠は経時的に残存率低下が認 められ，10週後で約 $45 \%$ となった.

$40^{\circ} \mathrm{C} / \mathrm{RH} 75 \%$ の条件下における残存率の変化を Fig. 4 に示す.シールの状態では, $40^{\circ} \mathrm{C} / \mathrm{RH} 50 \%$ の条件下では残存率低下が認められなかったワン
アルファ錠で著しい残存率低下が認められ，10週 後で約35\%に低下した。しかし，他の 3 製浏では 残存率低下は認められなかった。 バラの状態にお いては, アルファロール散, ワンアルファ錠とも 10週後で残存率が約 $20 \%$ と著しい低下が認められ た.ただし，アルファロール散の残存率低下は $25^{\circ} \mathrm{C}$ 条件の場合と同様 RH50\%よりも RH75\% の時の方が緩やかであった。軟カプセル 2 郕 は, $25^{\circ} \mathrm{C} / \mathrm{RH} 75 \%$ 条件の場合と同様, 残存率低 下は認められなかったが, カプセル皮浏の軟化が 認められた。

照度1000LUXの照度下 $\left(25^{\circ} \mathrm{C} / \mathrm{RH} 50 \%\right) に お ~$ ける残存率の変化を Fig. 5 に示す. シールの状 態では, ワークミンカプセルの10週後における残 存率が約 $85 \%$ と若干低下したが, 他の 3 製剤の残 存率低下は認められなかった。 バラの状態におい ては, ワークミンカプセルがシールの状態の時と ほぼ同様に, 若干の残存率低下が認められたのに 対して, 同じ軟カプセル剤であるアルファロール 


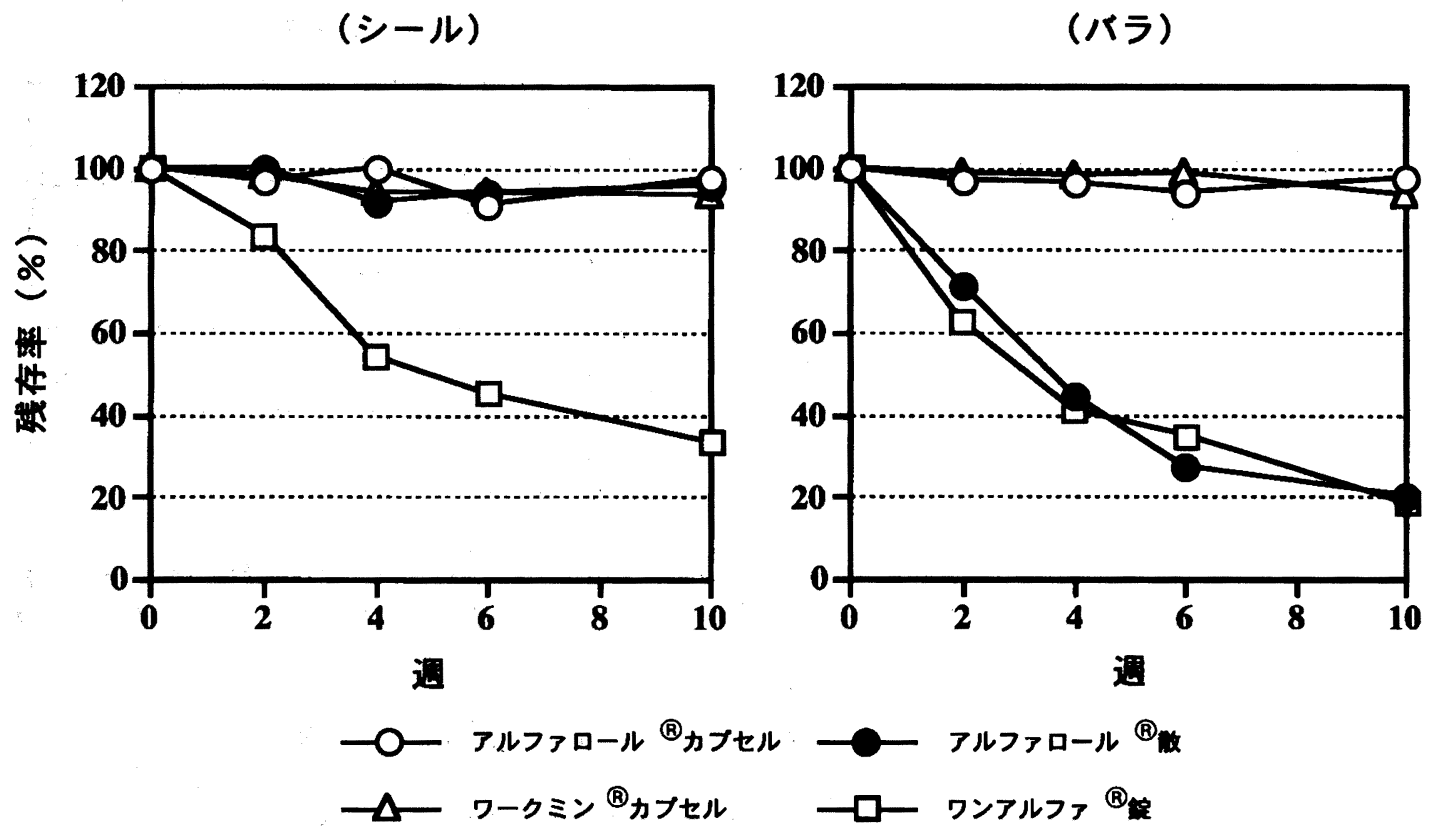

Fig. 4. $40^{\circ} \mathrm{C}, \mathrm{RH} 75 \%$ （遮光）の条件下における

各種アルファカルシドール製剤の残存率の変化
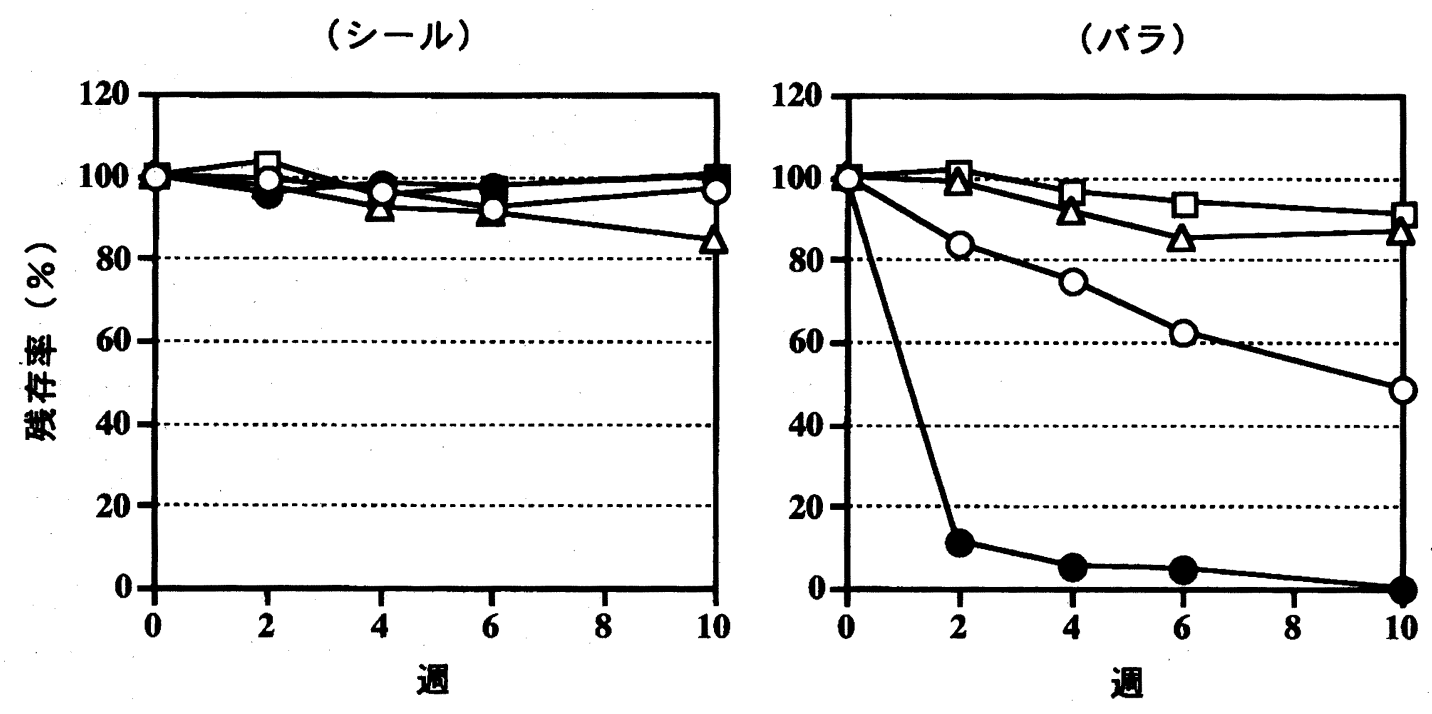

$$
\begin{aligned}
& \text { ○一 アルファロール }{ }^{\circledR} \text { カプセル - }- \text { アルファロール }{ }^{\circledR} \\
& \Delta \text { ワークミン }{ }^{\circledR} \text { カプセル - }
\end{aligned}
$$

Fig. 5. $25^{\circ} \mathrm{C}$, RH 50\%（1000 Lux 光照射）の条件下における 各種アルファカルシドール製剤の残存率の変化 


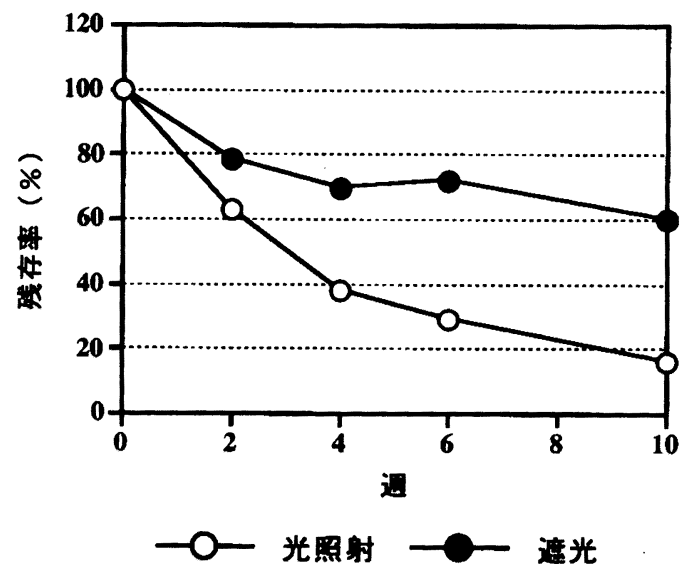

Fig.6. アルファロール散をセロハンラミ ネート紙で分包した際の残存率の変 化 $\left(25^{\circ} \mathrm{C}, \mathrm{RH} 50 \%\right)$

カプセルの10週後における残存率が約 $50 \%$ と大き く低下した。 また，アルファロール散では， 2 週 後の残存率が約10\%と著しく低下した。

アルファロール散をセロハンラミネート紙で分 包した試料を $25^{\circ} \mathrm{C} / \mathrm{RH} 50 \%$, 照度1000LUX の光 照射および遮光の条件下における残存率の変化を Fig. 6 に示す. いずれも経時的に残存率低下が認 められ, 10 週までの残存率は, 光照射では約 15\%，遮光で約60\%に低下した。

Fig. 7 に, ワンアルファ錠粉砕後, $25^{\circ} \mathrm{C} / \mathrm{RH}$ $50 \%$, 照度 1000 LUX の光照射の条件および遮光 の条件下における残存率の変化を示す. 光照射で は経時的に残存率低下が認められ，10週後で約 50\%に低下した。遮光においても10週での残存率 は約85\%と若干の低下が認められた。

\section{考察}

各種保存環境下におけるアルファカルシドール の残存率では，アルファロールカプセル，ワーク ミンカプセルの軟カプセル 2 剤は, 今回行った温 度・湿度の条件下でバラ, シールとも10週までに 残存率低下は認められず, 温度, 湿度の影響を受 けにくいものと考えられた。しかし，RH75\%の 条件では, 温度 $25^{\circ} \mathrm{C}, 40^{\circ} \mathrm{C}$ のずれにおいても軟
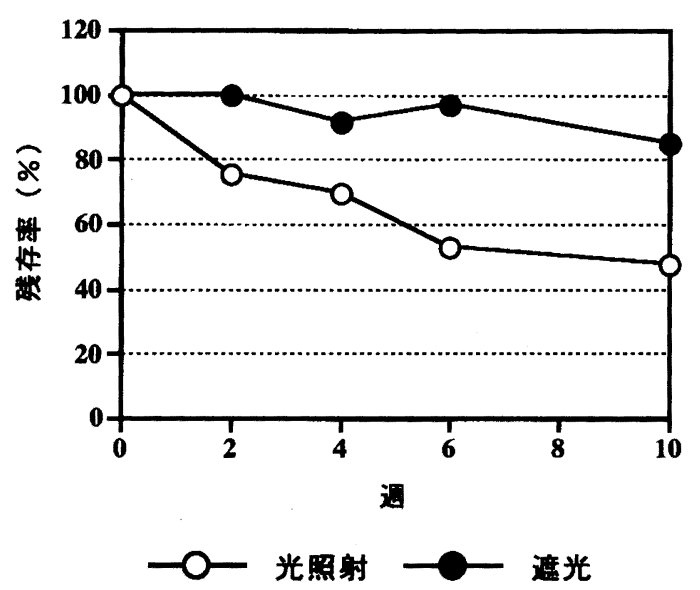

Fig. 7. ワンアルファ錠を粉砕しセロハンラ ミネート紙で分包した際の残存率の 変化 $\left(25^{\circ} \mathrm{C}, \mathrm{RH} 50 \%\right)$

カプセルの皮膜の軟化を認め, PTP シールからの 取り出しが困難となった. 残存率低下は認められ なかったが，高湿度での保存は避けるべきである と考えられた，一方，光に対しては両製剈とも残 存率への影響が観察され, 特に, アルファロール カプセルのバラの状態での低下は大きかった。し かし，アルファロールカプセルはPTP シールに UV カットの加工がなされていることから，シー ルの状態での保存では特に問題ないと考えられ た.また，ワークミンカプセルは，バラの状態に おいても残存率低下は少なかった。

ワンアルファ錠は, 温度 $25^{\circ} \mathrm{C}$ 条件下において は, RH75\%のバラで若干の残存率低下が認めら れた以外は湿度，光に対してほぼ安定であった が, 温度 $40^{\circ} \mathrm{C}$ 条件下においては大きな残存率低 下が認められた。 その残存率の低下傾向は，温度 $40^{\circ} \mathrm{C}$ 条件下の $\mathrm{RH} 75 \%$ バラ, RH75\%シール, RH $50 \%$ バラ, 温度 $25^{\circ} \mathrm{C}$ 条件下の RH75\%の順であっ た.また，ワンアルファ錠は錠犁のままでは光照 射による大きな残存率低下は認められなかった が, 粉砕後セロハンラミネート紙で分包した後で は，光の照射により大きな残存率低下が認められ た。これは，同じ粉砕したものでも遮光の条件下 では大きな残存率低下が認められなかったことか 
ら見て，粉砕により光照射を受ける面積が増大し たためではないかと考える，本結果より，錠剤を 粉砕した後の保存には光に対して注意をはらう必 要があるといえる。

今回行った試験条件において，アルファロール 散は，アルミシール包装の状態では残存率の低下 は認められなかったが，アルミシール包装を開封 したバラの状態では速やかに残存率は低下した。 また，バラの状態で, 温度 $25^{\circ} \mathrm{C}, 40^{\circ} \mathrm{C}$ 両条件と も RH75\%よりも RH50\%のほうが残存率の低下 は顕著であった。外観の性状として，RH50\%の 条件においてはシャーレに入れた散剤の上層部か ら下層部まで一様に微黄変化し固結が認められた のに対し，RH75\%の条件においては散剂の上層 部のみ黄変し皮膜状に強固な固結が認められ，下 層部は外観上試験開始時の状態を保っていた。 RH75\%の条件においては散剤の下層部が上層部 に生じた強固な固結が保護膜様の作用を示し， RH50\%条件下より残存率の低下が抑制されたも のと推察された。実際, $40^{\circ} \mathrm{C} / \mathrm{RH} 75 \%$ 条件で試 験開始 2 週後でアルファカルシドール含量を上層 部と下層部で別々に定量したところ，両者の間に は約 4 倍の含量の差が認められた。 また, 分包後 は $25^{\circ} \mathrm{C} / \mathrm{RH} 50 \%$ 条件下で遮光して保存したもの に打いてもかなりの残存率低下が認められ，アル ファロール散はアルミシール包装を開封して調剤
することは避けるべきであると考えられた。 た，アルファロール散にはバラの包装が市販され ているが，今回の結果より開封後の残存率低下が 懸念される。

以上, PTP シート，アルミシール包装のままの 状態においては，今回試験した 4 製剤では，ワン アルファ錠が高温，高湿の条件で残存率低下が認 められた以外は, 残存率の著しい低下は認められ なかった。しかし，バラの状態においては温湿 度，光によって残存率の低下する製刋が見られ， バラの状態でワンドースの機械のカートリッジに 装着した後, ワンドース包装後の残存率低下には 注意が必要になると考えられる.

また，アルファカルシドール製剤は副甲状腺の 機能低下症に対して90日投与が認められている が，錠剤を粉砕したもの，散剤を分包し直したも のを長期に投与することは避けるべきであると考 えられた。

\section{引用文献}

1) 古川洋太郎, 三浦良, 水梨一利, ホルモンと臨 床, 40, 1075-1083 (1992).

2) R. G. Russell, R. Smith, R. J. Walton, C. Preston, R. Basson, R. G. Henderson and A. W. Norman, Lancet., 2 (871), 14-17 (1974).

3) 鈴木時紀, 石川安信, 二橋喜一郎, 病院薬学, 19, 503-508 (1993). 